\title{
Monotypic colonies of Clathropteris meniscioides (Dipteridaceae) from the Early Jurassic of central Patagonia, Argentina: implications for taxonomy and palaeoecology
}

\author{
by \\ Thereis Y.S. Choo, Ignacio H. Escapa, and Benjamin Bomfleur
}

With 6 plates, 3 text-figures and 1 table

\begin{abstract}
A collection of over 130 specimens of the fossil dipterid fern Clathropteris meniscioides (BRONGN. 1825) BRONGN. 1828 from in-situ colonies in the Lower Jurassic of Chubut, Argentina, provides evidence for population-level morphological variation within the species and palaeoecology of the site. Characters such as angle of insertion of secondary veins, tertiary vein arrangement and tooth depth were observed to vary between specimens, and the total range of variation captured by this population was found to overlap and intergrade with the descriptions of several previously identified Clathropteris species. This suggests that species delimitations based on minor differences in such characters should be regarded with skepticism, and that the current number of species ascribed to this genus may be artificially inflated. Abundant $C$. meniscioides fossils at different development stages buried together in a single, thick bed of sheet-flood deposits provide evidence for the species having formed large, pure colonies in open, disturbed floodplain areas. The characteristic and extremely high leaf-vein densities would have allowed for greater carbon assimilation and rapid growth rates. Altogether, this suggests that the species was a fast-growing pioneer species of floodplains, a prominent part of the Early Jurassic vegetation in Gondwana, and a likely food source for large herbivorous dinosaurs common at that time.
\end{abstract}

Key words: Jurassic; Dipteridaceae; taxonomy; palaeoecology; in-situ ferns

\section{Contents}

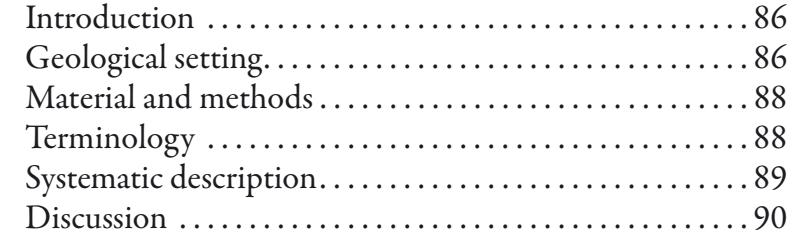

The generic status of Clathropteris ............. 90

Delimitation of Clathropteris species .............91

Palaeoecology of Clathropteris meniscioides ............ 94

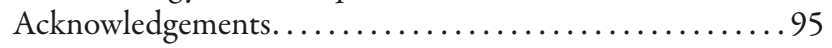

References............................. 95

Plates $1-6$ and explanation of plates............. 98

\footnotetext{
Authors' addresses:

Thereis Y.S. Choo, Section of Plant Biology, 412 Mann Library, School of Integrative Plant Science, Cornell University, Ithaca, New York 14853, USA

Thereis Y.S. Choo, National Parks Board, Singapore Botanic Gardens, 1 Cluny Road, Singapore 259569

ytc4@cornell.edu Ignacio H. Escapa, CONICET, Museo Paleontológico Egidio Feruglio, Av. Fontana 140, Trelew U9100GYO, Chubut, Argentina iescapa@mef.org.ar Benjamin Bomfleur, Department of Palaeobiology, Swedish Museum of Natural History, Svante Arrhenius Väg 7, SE-104 05 Stockholm, Sweden benjamin.bomfleur@nrm.se
} 


\section{Introduction}

The Dipteridaceae SEWARD 1900 is an early-diverged leptosporangiate fern lineage (SCHUETT PELZ \& PRYER 2007; LEHTONEN 2011). It contains about 11 extant species in two genera, Dipteris REINw. 1825 and Cheiropleuria C. Presl 1851 (Kramer et al. 1990; KATO et al. 2001). The two genera share a characteristic venation pattern with many orders of veins that are highly reticulated and form a dense meshwork of areoles with included free-ending veinlets (HOLTTUM 1954; Kramer et al. 1990; Kato et al. 2001). Dipteris and Cheiropleuria occur in warm tropical to sub-tropical regions of Asia, Australia and Polynesia (Corsin \& WATERLOT 1979; Kramer et al. 1990), where they are generally found at higher altitudes in open exposed areas (Holttum 1954; KRAMER et al. 1990). Whereas the Dipteridaceae is only a minor component of today's vegetation, the family has an extensive fossil record and was an important element of many Late Triassic and Early Jurassic floras across the globe (Seward \& Dale 1901; Corsin \& Waterlot 1979; Wing \& Sues 1992; Tidwell \& Ash 1994; Cantrill 1995; Skog 2001; van KoniJnenburgVAN Cittert 2002).

The earliest fossils with the distinctive venation pattern of Dipteridaceae are from the Middle Triassic (WebB 1982; Tidwell \& Ash 1994; Cantrill 1995; Kustatscher \& VAN Konijnenburg-VAN CITTERT 2011), suggesting that the origin of the family likely dates back into the Early Triassic or the Late Paleozoic (Tidwell \& Ash 1994). Dipteridaceae fossils have been found in Mesozoic deposits on all continents (e.g., ZeILler 1903; NATHORST 1906; Berry 1918; Oishi \& Yamasita 1936; FrenGUELLI 1941; HARRIS 1961; CORSIN \& WATERLOT 1979; Webв 1982; Stockey et al. 2006; Bomfleur \& Kerp 2010; WANG et al. 2014), and include six commonly recognized genera: Dictyophyllum LINDL. \& HutTon 1834, Clathropteris BRONGn. 1828, Camptopteris C. Presl 1838, Goeppertella OISHI \& K.Yamasita 1936, Hausmannia Dunker 1846, and Thaumatopteris Goepr. 1841. The Dipteridaceae reached its greatest generic diversity in the Early Jurassic (CORSIN \& WATERLOT 1979; Tidwell \& ASH 1994; CANTRILL 1995), mainly occupying moist localities in the temperate-warm and subtropical zones (van Konijnenburg-van CitTert 2002). Increasing aridity brought about during the onset of the Late Jurassic and Cretaceous is believed to have contributed to the decline in diversity of the family (SKOG 2001; van Konijnenburg-van Cittert 2002); the Cretaceous and Paleogene fossil record of Dipteridaceae is sparse and consists only of various species of Hausmannia (CANTRILl 1995; STOCKey et al. 2006).

Whereas Clathropteris has long been considered one of the most common ferns in the Upper Triassic and Lower Jurassic of Eurasia (SEwARD \& DALE 1901; CORSIN \& WATERLOT 1979), its record from Gondwanan continents is sparse (CoRsin \& WATERLOT 1979) and seemingly restricted to a few sites in Argentina and Antarctica (Herbst 1966; WebB 1982; YaO et al. 1991; Rees 1993; Bomfleur \& KeRp 2010). Here, we describe remarkable (par)autochthonous mass occurrences of an unusually large Clathropteris species in the Lower Jurassic of Cerro Bayo, Argentina (Text-fig. 1). Our collection includes fertile and sterile material, as well as fronds at different developmental stages. This provides a valuable opportunity to re-examine the taxonomy of the genus. The Cerro Bayo site also has an interesting geological setting, with Clathropteris fossils varying in relative abundance between the different depositional beds. These observed patterns offer insights into the palaeoecology of this Jurassic site, and the ecological role Clathropteris may have played.

\section{Geological setting}

The Cerro Bayo locality is situated near Gastre in the northwest part of Chubut Province, Argentina (Text-fig. 1) and has been described in detail in previous works (Escapa et al. 2014; Elgorriaga et al. 2015). Plant horizons at this locality belong to an unnamed unit of fluvially reworked, volcaniclastic deposits, which are overlain by agglomerates and lavas of the Lonco Trapial Formation and by lacustrine deposits of the Cañadón Asfalto Formation. Previous radiometric studies have dated the site into the Early Jurassic (most likely Pliensbachian) (CúnEO et al. 2013; EscAPA et al. 2014).

Most of the dipterid fossils described here were collected from three thick $(\sim 1 \mathrm{~m})$ beds of volcaniclastic siltstone extensively exposed at numerous sites in the Cerro Bayo area. The fossils are of a single Clathropteris species. The low diversity in these Clathropteris beds, the common preservation of almost complete fronds and upright stipes, and the occurrence of fronds preserved at different developmental stages (including croziers) together indicate in-situ burial of 


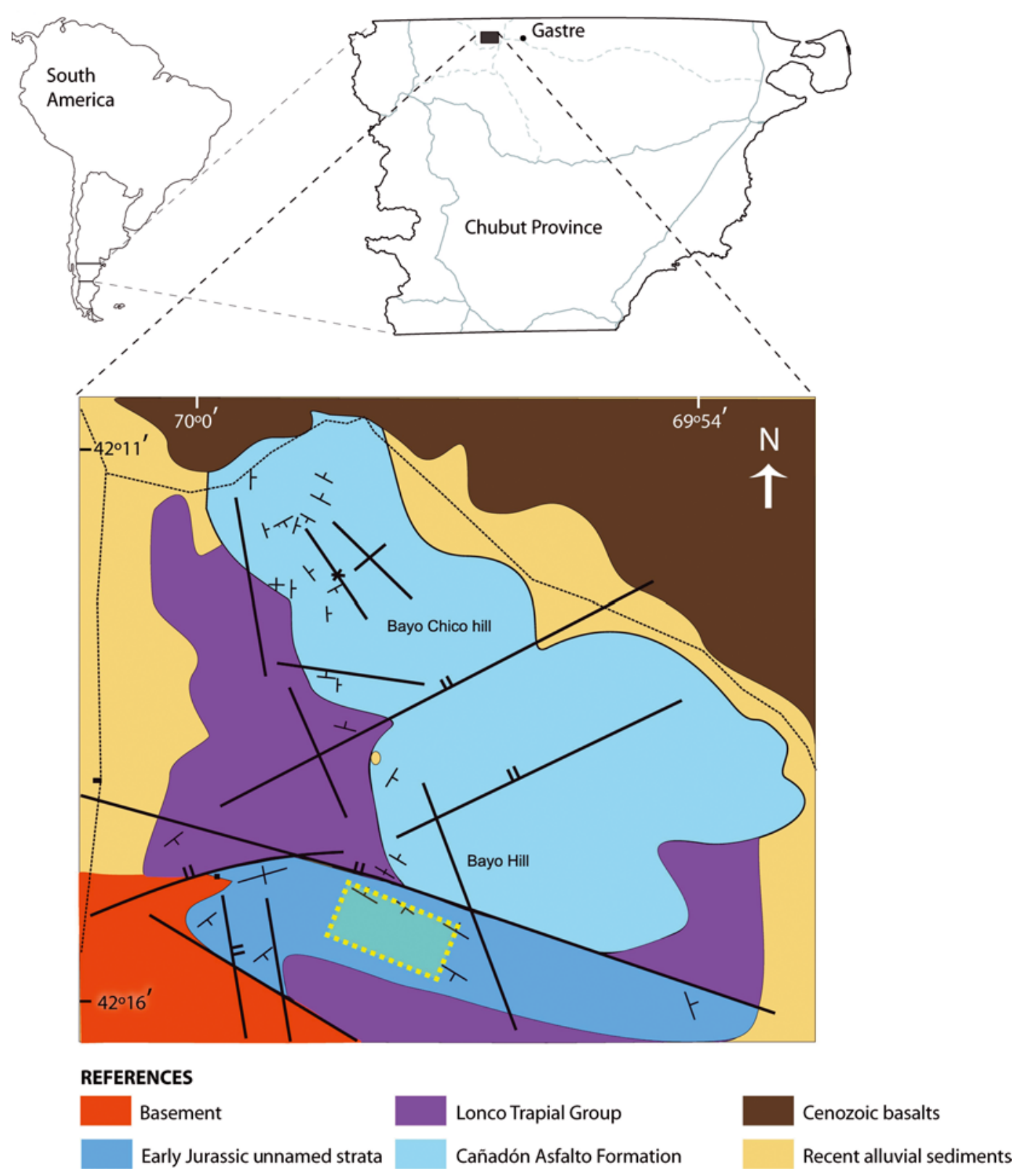

Text-fig. 1. Location and geology of the Cerro Bayo locality where the Clathropteris meniscioides fossil material was collected.

large colonies during catastrophic depositional events. These thick Clathropteris beds are succeeded by thin beds of partially silicified sediments that contain a taphocoenosis dominated by conifers and ferns (EsCAPA et al. 2014; ElgorRIAGA et al. 2015), including a few specimens of Clathropteris. Species that have been described from this site include Austrohamia minuta EsCAPA, Cúneo \& Axsmith 2008 (Cupressaceae; EsCAPA et al. 2008), Todites cacereii EsCAPA \& CúNeO 2012 and Osmundopsis rafaelii EsCAPA
\& CÚNeo 2012 (Osmundaceae; EsCAPA \& CÚNEO 2012), Marattiopsis patagonica EsCAPA, BOMFLEUR, Cúneo \& SCASso 2014 (Marattiaceae; EsCapa et al. 2014), and Equisetum dimorphum Elgorriaga 2015 (Equisetaceae; Elgorriaga et al. 2015). Additional sporadic finds of seed ferns (e.g., Caytoniales) and of another member of Dipteridaceae are still awaiting detailed systematic treatment (EsCAPA et al. 2014). 


\section{Material and methods}

The material comprises about 135 specimens that are housed in the Museo Paleontológico Egidio Feruglio Palaeobotanical Collection in Trelew, Argentina (hereafter MPEF-Pb). Most specimens occur in the form of well-defined, conspicuous, rustcoloured impressions of vegetative and fertile fronds; stipes are commonly preserved as compressions and casts. Photographs of specimens were taken with a Canon EOS 7D camera equipped with a Canon EF-S $60 \mathrm{~mm}$ macro lens; additional extension tubes were used in order to obtain higher magnifications. In order to obtain greater depth of focus for high-magnification images, we used an image-stacking technique (BERCOVICI et al. 2009) in which one well-focused image is obtained via merging several individual photographs captured at slightly different focal planes. Images were checked and edited for the presence of artifacts related to the stacking process, edited for colour balance, and cropped for publication using Adobe Photoshop. Thin sections of compressed stipes that showed evidence of partially preserved internal anatomy were also prepared. Fine details of the compression/impression specimens and the thin sections were studied using a Zeiss MC80DX stereoscope microscope. Selected fertile specimens were additionally examined using a scanning electron microscope (JEOL JSM-6460) without prior coating.

\section{Terminology}

All members of Dipteridaceae share the same basic architectural plan (Text-fig. 2). The stipe dichotomizes into two axes (herein termed 'rachial arms') to form a bilaterally symmetrical frond (Oishi \& Yamasita 1936; Holttum 1954). Each rachial arm subsequently dichotomizes catadromously to give rise to lamina segments that-depending on the degree of lamina dissectionhave been referred to as pinnae (e.g., OISHI \& YAMASITA 1936), lobes (e.g., Holttum 1954), frond members (e.g., Rees 1993), or primary segments (e.g., NATHORST 1906). We have chosen to apply the descriptive term 'primary segment' (Text-fig. 2) as it is independent from the degree of lamina dissection and can thus be used consistently across different Dipteridaceae. Frond venation is another important character in the Dipteridaceae. In particular, shape and size of the areoles bounded by the secondary and tertiary veins have been used to distinguish genera (OISHI \& YAMASITA 1936). We refer to the areoles bounded by the highest-order veins as ultimate areoles, and specify the surrounding vein orders when referring to larger areoles (e.g., areoles bounded by secondary and tertiary veins; Text-fig. 2).

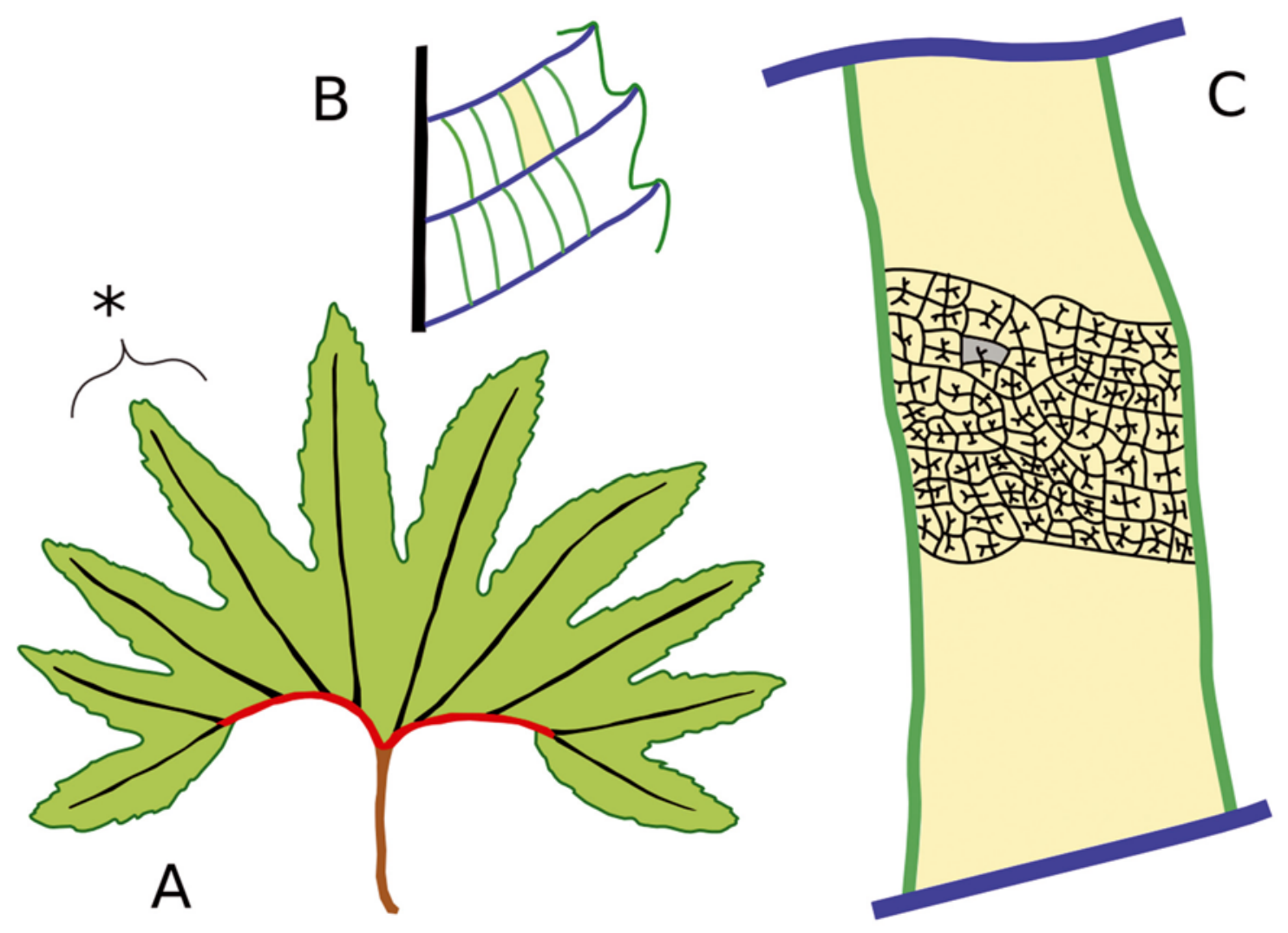

Text-fig. 2. Illustration of terminology used. A. Diagram showing Dipteridaceae frond architecture with the stipe (brown), rachial arms (red), primary veins (black), and one primary segment $\left(^{*}\right)$ highlighted. B. Close up of a primary segment showing the areoles formed by the secondary veins (blue) and tertiary veins (green). C. Close up showing the meshwork of higher order veins and an ultimate areole (highlighted in grey). 


\section{Systematic description}

\author{
Family Dipteridaceae SEWARD 1900 \\ Genus Clathropteris BRONGN. 1828
}

1828

Clathropteris Brongn., p. 62

Type species: Clathropteris meniscioides (BRONGN. 1825) BRONGN. 1828; by original designation.

\section{Clathropteris meniscioides ${ }^{1}$ (BRONGN. 1825) BRONGN. 1828 \\ Plates 1-6 \\ 1825 Filicites meniscioides Brongn., p. 218; pl. 11. \\ 1828 Clathropteris meniscioides (BRONGN.) BRONGN., p. 62}

Specimens examined: MPEF-Pb 1564-1565, 1732, 1771, 1784, 1857, 2214, 2669, 2691, 2696, 2703, 2707-2708, 2713, 2732, 2735, 2742, 2744, 2749, 2755, 2758, 2762, 2766, 2773, 2780, 2794, 2801, 2808, 2811, 2814-2815, 3400-3406, 3411-3412, 3417-3418, 3422-3423, 3425-3426, 3428-3430, 3436, 3443, $5055-5058,5272-5277,5331-5334,5337-5339$, 5352-5353, 5355-5358, 5382-5391, 5394-5398, 5513-5514, 5516, 5518, $5621,5624,5667-5672,5678,5680,5683,5688,5692,5695-$ 5696, 5727, 5729-5732, 5735-5740, 5744-5745, 5748-5749, 6435-6437, 6544, 6566, 6584, 6587, 6596, 6599, 6950, 6970, 6997-6999.

Description: Stipes are up to $3 \mathrm{~cm}$ wide (Pl. 2, Fig. 2). Their complete length is unknown, but the longest stipe fragment is $12.5 \mathrm{~cm}$ long and $0.5 \mathrm{~cm}$ wide (Pl. 1 , Fig. 1). Stipes are generally subterete in cross section, with a pronounced central longitudinal groove on the adaxial surface and two smaller, parallel longitudinal grooves on the abaxial surface (Pl. 5, Fig. 6); the grooves commonly appear as longitudinal ridges in compressed specimens (Pl. 1, Fig. 2; Pl. 5, Fig. 4). The stipe surface is otherwise smooth. Stipe vasculature comprises in cross section a single $\mathrm{C}$-shaped bundle with incurved tips (Pl. 5, Fig. 6).

The fronds are large, bilaterally symmetrical, and flabellate (Pl. 1, Fig. 1; Pl. 2. Fig. 1). The precise maximum size is unknown, but is probably exceeding $1.5 \mathrm{~m}$ in diameter. Lamina is regularly incised to more than $2 / 3$ of the total length, typically forming 12 (but possibly up to 16) about equally sized, lanceolate to oblanceolate primary segments (Pl. 1, Fig. 1; Pl. 2, Figs 1-4; Pl. 3, Figs 1-2; Pl. 4, Figs 1-3) that are separated by wide sinuses (Pl. 3, Fig. 2). Primary segments probably reached up to $70 \mathrm{~cm}$ in length, the largest specimen of a complete primary segment having a length-to-width ratio of $\sim 6: 1(22.3 \mathrm{~cm}$ in length and $3.8 \mathrm{~cm}$ at its widest point) (Pl. 2, Fig. 1) and the largest incomplete segment being $12 \mathrm{~cm}$ wide and over $34 \mathrm{~cm}$ long (Pl. 3 , Fig. 1). Frond lamina glabrous and the margin of the primary segments is serrate (Pl. 3, Figs 1-3; Pl. 4, Figs 2-3; Pl. 5, Figs 1-2). Teeth occur at intervals of 9-17 $\mathrm{mm}$ and are incised to $4-10 \mathrm{~mm}$ depth, corresponding to $\sim 20-40 \%$ of the length of the secondary vein that enters the tooth (Pl. 3, Figs 1-3; Pl. 5, Fig. 2 ). Each tooth is triangular to slightly falcate, with a straight to slightly concave acroscopic margin and a convex basiscopic margin. The tooth apex is inclined apically at an angle of $\sim 20-45^{\circ}$ to the primary vein of the segment (Pl. 3, Figs 1-3; Pl. 5, Fig. 2).

The base of the frond blade is composed of two equal, opposite rachial arms up to $8 \mathrm{~mm}$ thick (Pl. 2, Figs 2-4). Each rachial arm undergoes a series of 5 (or occasionally 6 or 7 ) catadromous dichotomies (the final dichotomy being more or less isodromous) at intervals corresponding to 2-4 times the basal width of the rachial arm (i.e., 4.5-20 mm) (Pl. 2, Figs 2-4; Pl. 4, Fig. 1). Acroscopically, the dichotomies give rise to 6-8 primary veins, which depart at angles of $30-60^{\circ}$ (rarely up to $\sim 80^{\circ}$ ), the angle of insertion generally decreasing with each successive dichotomy giving the architecture a flabellate appearance (Pl. 2, Figs 2-4; Pl. 4, Fig. 1). Each primary vein forms the main axis of a primary segment (Pl. 3, Figs 1-2; Pl. 4, Figs 1-3). Primary veins are simple and straight, up to $3.5 \mathrm{~mm}$ wide at the base and tapering to $\sim 0.1 \mathrm{~mm}$ at the apex of the primary segment (Pl. 2, Figs 1-4; Pl. 3, Figs 1-2; Pl. 4, Figs 1-3). Secondary veins are (sub)opposite to alternate, and depart at angles between $55-80^{\circ}$ (typically $\sim 70^{\circ}$ ) and at regular intervals of $6-18 \mathrm{~mm}$, depending on the size of the frond (Pl. 3, Figs 1-3; Pl. 4, Figs 4-5). Secondary veins are simple, straight, and $\sim 0.2-0.6 \mathrm{~mm}$ wide (Pl. 3, Figs 1-3; Pl. 4, Fig. 5; Pl. 6, Fig. 1). In the fused basal portion of the frond lamina, secondary veins become confluent at varying angles (Pl. 4, Fig. 4), whereas in the separate primary segments, each secondary vein terminates in a tooth

Most authors have adopted the spelling 'meniscoides' instead of the original 'meniscioides'. However, it is clear from the original description that BRONGNIART (1828) chose this name to indicate the similarity of the type material with extant Meniscium (now a subgenus of Thelypteris); hence, like NATHORST (1906), we propose that the original spelling 'meniscioides' (i.e., 'resembling Meniscium') should be preferred over of the more commonly used 'meniscoides' (i.e., 'resembling a crescent'; see HiTcHCOCK 1855). 
at the lamina margin (Pl. 3, Figs 1, 2; Pl. 5, Fig. 1-2); very rarely, secondary veins also converge in the free primary segments (Pl. 5, Fig. 3). Tertiary veins are generally opposite, $\sim 0.1-0.2 \mathrm{~mm}$ in width, and departing from secondary veins at $\sim 70-100^{\circ}$ (typically $85^{\circ}$ ) at regular intervals between 3-8 mm (Pl. 3, Figs 1-3; Pl. 4, Fig. 5). In the free, distal ends of the primary segments, most tertiary veins are monopodial, connecting to adjacent secondary veins in straight or slightly outward-curving lines to form a regular latticework of orthogonal areoles with the secondary veins (Pl. 3, Figs 1-3; Pl. 4, Fig. 5); tertiary veins are very rarely sympodial or forming a zig-zag pattern (Pl. 4, Fig. 6). In the fused basal portion of the frond, the arrangement and general appearance of the tertiary veins is irregular; they may appear sympodial, are sometimes indistinct from secondary veins, and generally form polygonal areoles (Pl. 4, Fig. 4). Across the lamina, the tertiary and higher-order veins depart at an angle of $\sim 90^{\circ}$ to form a fine reticulate mesh of square or rectangular ultimate areoles (Pl. 4, Fig. 7). Each ultimate areole is $\sim 0.2-1.0 \mathrm{~mm}^{2}$ in area, and most ultimate areoles enclose a single vein that dichotomizes to form two free-ending veinlets (Pl. 4, Fig. 7).

In fertile fronds, sori are scattered across the lamina surface without any apparent association with the major veins, although they become more dispersed towards the frond margins (Pl. 6, Fig. 1). Each sorus is positioned in an ultimate areole (although adjacent sori can become confluent and appear to take up more than one areole; Pl. 6, Figs 1-5), round, 0.5$1 \mathrm{~mm}$ in diameter, exindusiate, and composed of at least 8 (probably between $10-15$ ) sporangia that do not seem to be arranged in any regular order (Pl. 6, Figs 5-6). Sporangial capsules measure 200-300 $\mu \mathrm{m}$ in diameter (Pl. 6, Figs 6-7) and have a ring-like annulus that is composed of more than 12 cells (probably $25-30$ cells) $\sim 50 \mu \mathrm{m}$ in width (Pl. 6, Figs 7-8).

Comparisons: The new material from Cerro Bayo falls into the range of variation seen in the type species $C$. meniscioides (Table 1 ). This is evident by its very large size, lanceolate to oblanceolate shape of primary segments, moderately developed teeth (incised to up to $30 \%$ of the secondary-vein length), and mainly monopodial tertiary-vein architecture (Table 1). Similarly large fronds of Clathropteris have previously been described from Germany (GOEPPERT 1846), eastern North America (e.g., Fontaine, 1883), and Vietnam (Zeiller 1903), under the name C. platyphylla (Goepr. 1846) Brongn. 1849 (Table 1).
In Patagonia, several fragments of large Clathropteris fronds from Neuquén province, Argentina, were described as C. ingens Freng. 1941 (Frenguelli 1941). Frenguelli (1941) also reported a second Clathropteris species (C. kurtzii FRENG. 1941) from the same site that differs from $C$. ingens merely in its smaller size. Additional material of $C$. kurtzii was subsequently described from coeval deposits at other sites in Chubut province, Argentina (BonetTi 1963). In a review of the Patagonian fossils, Herbst (1966) considered both C. kurtzii and C. ingens to be insufficiently distinguishable and placed both in synonymy with C. obovata OISHI 1932. Our specimens are indistinguishable from the fragmentary specimens of $C$. ingens, and we are of the opinion that C. kurtzii is likely a juvenile form of $C$. ingens. However, whereas we agree with HERBST's (1966) decision to consider the two species as conspecific, we disagree with synonymizing the two species with $C$. obovata, as the type of the latter differs by deeper teeth and obovate primary segments. Instead, we consider $C$. ingens and $C$. kurtzii to be conspecific with $C$. meniscioides.

\section{Discussion}

\section{The generic status of Clathropteris}

Clathropteris was established in 1828 with the description of C. meniscioides from Höör, southern Sweden (BRONGNIART 1828), based on a detailed treatment of material earlier described under the name Filicites meniscioides BRONGN. 1825. BRONGNIART (1828) characterized the genus as being pinnatifid; having strong primary veins that extend to the extremities; and having many simple, parallel, secondary veins perpendicular to the primary vein and traversed by tertiary veins to form a meshwork of square areoles. However, not a single additional fossil has since been found to show the hierarchical pinnatifid architecture as illustrated by BRONGNIART (1825). Instead, the primary segments in all known fossils are disposed in a pedate manner (e.g., Goeppert 1846; Oishi 1932; Frenguelli 1941). Nathorst (1906) discussed the original description in detail and concluded that the illustration of $C$. meniscioides was inaccurate in its depiction of gross morphology since it was based merely on a sketch of the fossil as seen by the author on site during a field excursion led by Mr S. NilsSON (NATHORST 1906). Based on entries in S. Nilsson's field-book notes, NATHORST (1906) further argues that the original specimen was then later re- 
moved from the quarry and brought to the geological collection of Lund University. The specimen was subsequently transferred to the Swedish Museum of Natural History in Stockholm, where it is housed today. Nathorst (1906) then synonymized C. platyphylla with C. meniscioides, as these two species were considered identical apart from the misinterpreted simply-pinnate frond architecture of the latter. NATHORST's (1906) reinterpretation of the structure of the type species $C$. meniscioides is widely accepted and many authors have since described similar fossils from various localities worldwide as $C$. meniscioides (e.g., Oishi \& Yamasita 1932; Kon'no 1968; Cornet \& Traverse 1975; SCHWEITZER et al. 2009; BomFLEUR \& KeRP 2010; WANG et al. 2015).

Past authors have held differing views on the taxonomic rank of Clathropteris and its relationship with Dictyophyllum. Both genera are similar in gross morphology and differ mainly in their venation pattern, with Dictyophyllum lacking the regular orthogonal latticework of tertiary and higher-order veins seen in Clathropteris (SEWARD \& Dale 1901; Nathorst 1906; Oishi \& Yamasita 1936; Herbst 1992); the numbers and sizes of sporangia have been considered as further delimiting features (OIsHi \& Yamasita 1936). These boundaries are not always entirely clear, as the variation in all these characters appears to overlap and intergrade between species and even individual specimens (Kon'No 1968; CANTRILl 1995). Nevertheless, many authors - including, e.g., NATHORST (1906), Berry (1918), and Oishi \& Yamasita (1936) - consider the variation in characters as significant and sufficiently useful to separate these taxa at the rank of genus, and the genus Clathropteris is widely used today (e.g., Wang 2002; Schweitzer et al. 2009; BOMFLEUR \& KeRP 2010). Other authors, by contrast, advocate merging Clathropteris as a subgenus into Dictyophyllum (SEWARd \& Dale 1901; Herbst 1992).

\section{Delimitation of Clathropteris species}

The orthogonal venation pattern of Clathropteris is highly distinctive, making genus identification even of small fossil fragments easy. It is therefore unsurprising that a relatively large body of literature on this genus exists. Over 20 species of Clathropteris have been described (see Jongmans 1959; Dijkstra 1967; Boersma \& BroekMeYer 1986; Zhou et al. 2015). Characters commonly used for species diagno- ses include the number, size, and shape of primary segments (Oishi 1932; Frenguelli 1941; Ash 1970); tooth shape (OISHI 1932); the angle of insertion of secondary veins (HEER 1877; ZHOU et al. 2015); the 'distinctness' of tertiary and quaternary veins (OISHI 1940; Schweitzer et al. 2009); and the size and number of sporangia per sorus (AsH 1970). A further character that is sporadically mentioned in the discussion of species boundaries, but is rarely used as a diagnostic character, is tertiary vein appearance (HERBST 1966; Kon'No 1968). However, inadequate descriptions, ambiguous features, incomplete preservation of type specimens, poor knowledge about the diagnostic significance of morphological features, and the high morphological variability of Clathropteris species renders the delimitation of many species difficult or impossible. As a result, many earlier-described species have since been merged into one of the two common and broadly defined species, $C$. meniscioides and C. obovata (e.g., Jongmans 1959; Herbst 1966; Kon'no 1968; Litwin 1985; Schweitzer et al. 2009; BOMFLEUR \& KeRP 2010).

The large collection from Cerro Bayo is valuable as it captures the morphological variation found within a single colony, allowing for an objective assessment of some of the quantitative characters that are commonly used for species diagnoses. For instance, based on our short survey of several Clathropteris specimens, including the type specimens of 8 species (Table 1 ), only two reported specimens, C. pekingensis (see ZHOU et al. 2015) and C. obovata (WANG et al. 2015) have angles of insertion of secondary veins that fall outside the range observed in the Cerro Bayo specimens. Notably, while HARRIS (1961) stressed that a smaller insertion angle was diagnostic of $C$. obovata, photographs from the original species protologue (OISHI 1932) show the type specimen to have insertion angles comparable to $C$. meniscioides.

Another highly variable character among the Cerro Bayo specimens is tooth depth: the total range in variation overlaps with all the published specimens we surveyed (Table 1) except for the type specimen of $C$. obovata, which has significantly deeper teeth (OISHI 1932; Oishi \& Yamasita 1936). However, other specimens of C. obovata (e.g. HerbSt 1966; WANG et al. 2015) have much shallower laminal teeth.

The current records on the number of sporangia per sorus also appear to be too variable to be useful. In addition, based on our knowledge on the biology of extant Dipteris, it is a character that is difficult to 


\begin{tabular}{|c|c|c|c|c|c|c|c|c|c|c|c|}
\hline 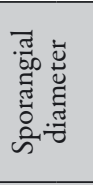 & 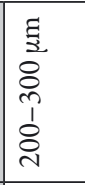 & 1 & 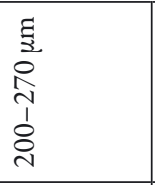 & 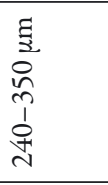 & 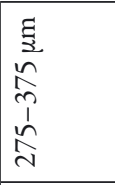 & & 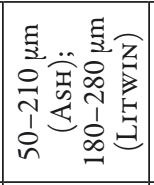 & 1 & 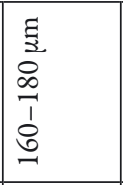 & 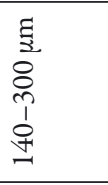 & 1 \\
\hline 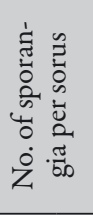 & $\frac{\pi}{\infty}$ & 1 & $\begin{array}{l}\frac{\pi}{1} \\
\stackrel{1}{\circ} \\
\stackrel{0}{1}\end{array}$ & $\begin{array}{l}n \\
0 \\
0 \\
\xi\end{array}$ & $\begin{array}{l}0 \\
0 \\
0 \\
0 \\
1\end{array}$ & . & 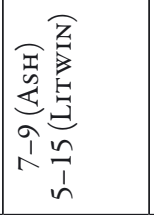 & 1 & 1 & $\begin{array}{l}\stackrel{i}{1} \\
\stackrel{1}{a}\end{array}$ & I \\
\hline 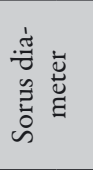 & 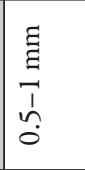 & 1 & 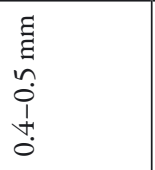 & I & 1 & & 1 & 1 & 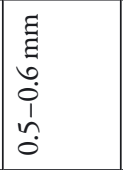 & 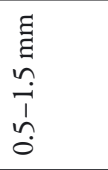 & 1 \\
\hline 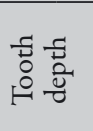 & $\begin{array}{l}0 \\
\text { ò } \\
1 \\
1 \\
2\end{array}$ & 1 & 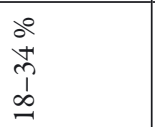 & I & 1 & $\stackrel{d}{\hat{v}}$ & ڤั & 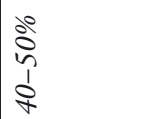 & $\begin{array}{l}\stackrel{2}{\hat{~}} \\
\text { 2 }\end{array}$ & ฉ̊? & $\frac{1}{2} a^{\circ}$ \\
\hline 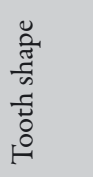 & 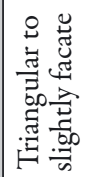 & 1 & 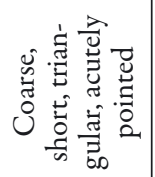 & 1 & 1 & 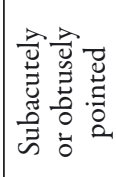 & 苞 & 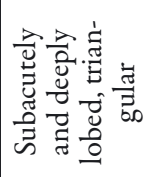 & 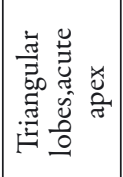 & 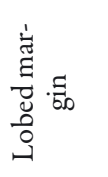 & 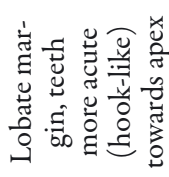 \\
\hline 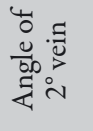 & $\begin{array}{l}0 \\
\infty \\
\infty \\
1 \\
n \\
n\end{array}$ & $\begin{array}{l}: \\
0 \\
1 \\
0 \\
0\end{array}$ & $\begin{array}{l}: 0 \\
0 \\
i \\
\vdots\end{array}$ & 六 & $\begin{array}{l}i \\
i \\
i \\
i \\
i\end{array}$ & $\begin{array}{l}0 \\
0 \\
1 \\
1 \\
0\end{array}$ & $\begin{array}{l}0 \\
0 \\
i n \\
1 \\
o+1\end{array}$ & 章 & 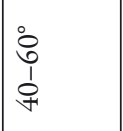 & 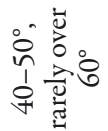 & : \\
\hline 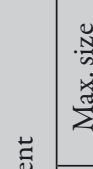 & 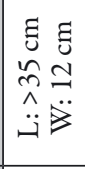 & 1 & $\begin{array}{l}\tilde{E} \\
\tilde{\omega} \\
\tilde{\sigma} \\
\ddot{y}\end{array}$ & 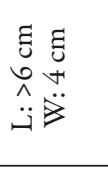 & 1 & 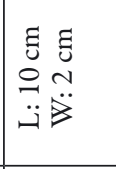 & 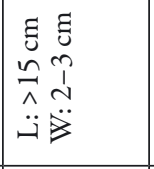 & 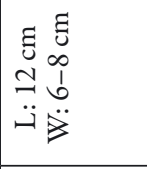 & 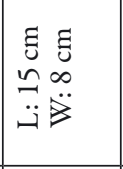 & 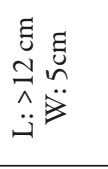 & 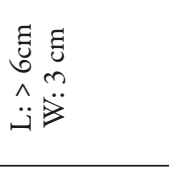 \\
\hline 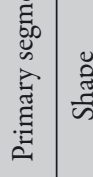 & 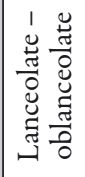 & 1 & 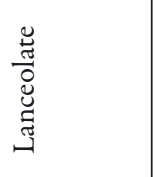 & 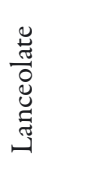 & 1 & & 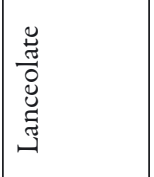 & 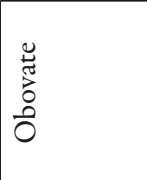 & 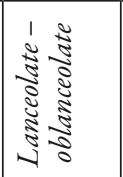 & 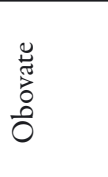 & 1 \\
\hline 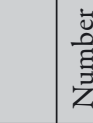 & $\begin{array}{l}6 \\
\stackrel{1}{1} \\
\cong \\
=\end{array}$ & 1 & 1 & I & 1 & $\stackrel{\infty}{+}$ & 站 & 1 & $\frac{\widehat{i}}{\pi}$ & 1 & 1 \\
\hline 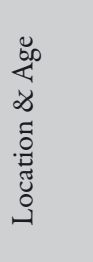 & 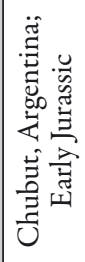 & 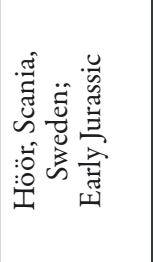 & 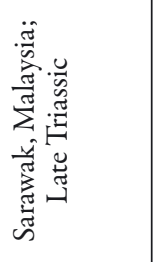 & 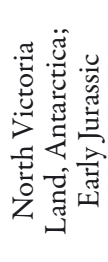 & 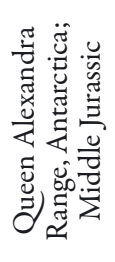 & 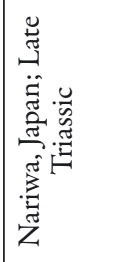 & 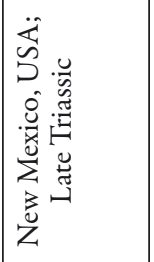 & 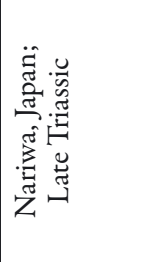 & 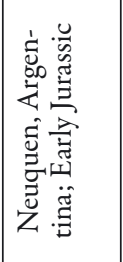 & 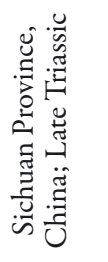 & 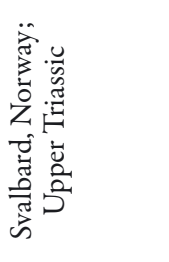 \\
\hline 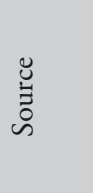 & 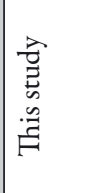 & 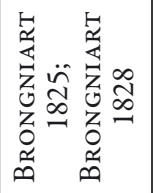 & $\begin{array}{l}\infty \\
2 \\
2 \\
0 \\
z \\
z \\
a \\
\end{array}$ & 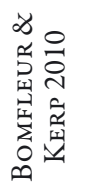 & 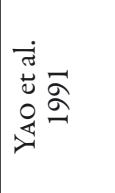 & 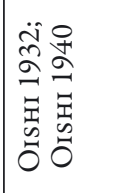 & 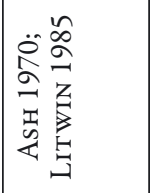 & 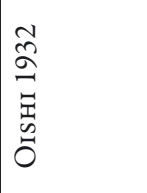 & 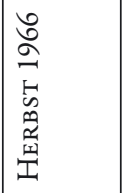 & 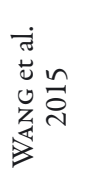 & 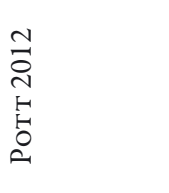 \\
\hline 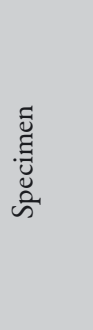 & 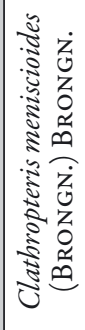 & 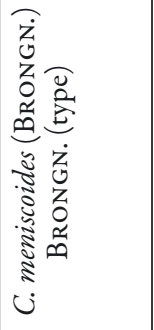 & 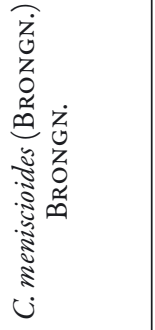 & 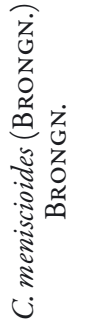 & 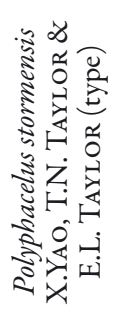 & 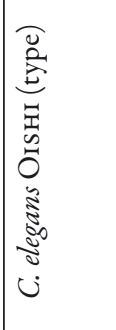 & 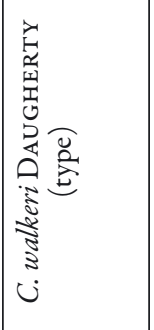 & 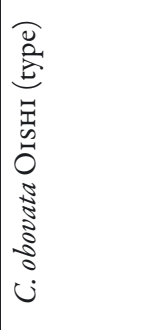 & 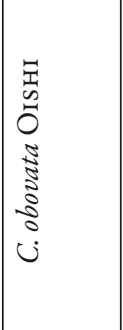 & 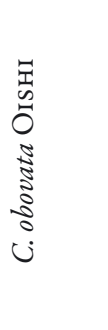 & 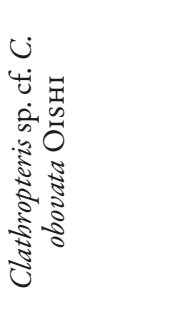 \\
\hline
\end{tabular}




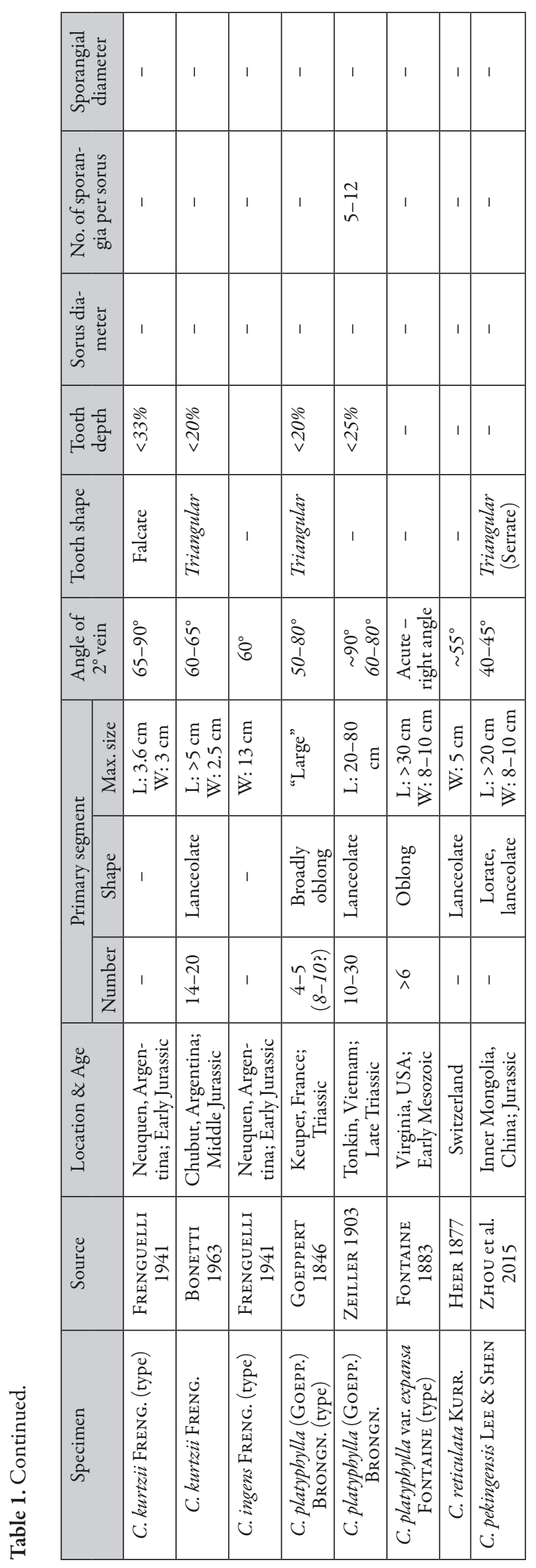

measure and should be regarded with caution. Each sorus of D. conjugata REINW. 1825 is known to be composed of many sporangia that have mixed maturation (Seward \& Dale 1901; Armour 1907), so a count at any single moment in time is likely to be an underestimate. At the same time, even though $D$. lobbiana (Hook. 1853) T. Moore 1857 is reported to have simultaneous sporangial maturation (ARMOUR 1907), determining the number of sporangia is still difficult because the sori are covered in a gummy substance before maturity (HoOKER 1853). The diameter of sporangial capsules is a more promising diagnostic character. However, the current paucity of records does not allow for clear distinctions to be made between different taxa. The few well-preserved sporangia from our specimens fall within the full range of all the fossils that have been ascribed to $C$. meniscioides. Interestingly, the Clathropteris specimens from Neuquén, Argentina, described by Herbst (1966) also have relatively small sporangia, suggesting that they are more closely aligned with our specimens than specimens of $C$. meniscioides found elsewhere.

Three characters, that are probably diagnostic but can be difficult to determine in fossil material, are the maximum size of fronds, number of primary segments per frond and shape of each primary segment. Our fully-intact specimens from Cerro Bayo are fairly regular in having 12 lanceolate primary segments per frond with only little variation. However, the Cerro Bayo collection is rather unusual in having a large number of intact fronds preserved. These characters are less useful for fragmentary material. The maximum size of fronds is especially difficult to determine from collections where no fertile material is present. In these cases, it is almost impossible to distinguish between mature and juvenile fronds, and maximum size estimates are likely to be underestimates.

Our specimens and the short comparative survey of various Clathropteris specimens suggest that many Clathropteris species cannot be adequately subdivided based on the available morphological features alone. Perhaps a much larger study including many more Clathropteris fossils and additional morphometric tools would be able to further partition the total amount of variation. If so, it would likely result in an overhaul of the taxonomy Clathropteris, or at the very least, require the assignment of epitypes to the current species descriptions to resolve differences between the type species. 


\section{Palaeoecology of Clathropteris meniscioides}

The Dipteridaceae is one of three families in the Gleicheniales, a clade that comprises mostly pioneering species of open, disturbed landscapes (HoLTTUM 1954; Kramer et al. 1990; Wing \& Sues 1992). Fossil evidence from Cerro Bayo provides support for Clathropteris meniscioides having occupied a similar ecological niche in the Early Jurassic of Patagonia. The presence of monotypic assemblages of C. meniscioides at different developmental stages in thick beds of presumable sheet-flood deposits, overlain by finer-grained lacustrine beds that contain a much richer and more diverse plant taphocoenosis (EsCAPA et al. 2008; EsCAPA \& CÚNEO 2012; EsCAPA et al. 2014; ElgorRIAGA et al. 2015), suggests that C. meniscioides formed large, prominent colonies in floodplains, and was largely absent in the more mature vegetation types. This is comparable to the ecological niche of Dipteris lobbiana, an extant rheophytic species that forms thickets in open areas along streams that are liable to sudden flooding (HoLTtum 1954; CHOo pers. obs.).

Venation characters provide further evidence for the palaeoecology of Clathropteris meniscioides. The Dipteridaceae is one of the few non-angiosperm lineages that independently evolved a reticulate hierarchical network with internally directed veinlets (BOYCE 2005). The family is also noteworthy in having one of the highest vein densities $\left(\sim 5 \mathrm{~mm} \mathrm{~mm}^{-2}\right)$ outside of the angiosperm clade (mean $\sim 8 \mathrm{~mm} \mathrm{~mm}^{-2}$, but up to $25 \mathrm{~mm} \mathrm{~mm}^{-2}$ ), and more than double the vein density of other ferns (mean $\sim 1.5 \mathrm{~mm} \mathrm{~mm}^{-2}$; BOYCE et al. 2009). This character is significant as venation density is highly correlated with transpiration and carbon assimilation rates (BRODRIBB et al. 2007; BoyCE et al. 2009). Thus, in environments where light and water availability were not limiting, such as open marshes and floodplains, it is likely that $C$. meniscioides would have been much more productive and grow significantly faster than other lineages. One disadvantage of highly irrigated leaves is a susceptibility to drying out in conditions where water is scarce. This may explain why extant Dipteridaceae species are only found in humid, tropical to subtropical regions (KRAMER et al. 1990), and why the family fossil record declines during the later part of the Jurassic, when climatic conditions became drier overall (SKOG 2001; VAN KonIJNENBURG-VAN CITTERT 2002).
In their review of Mesozoic ecology, WING \& SuEs (1992) noted that massive herbivorous dinosaurs were common in Gondwana from the Middle Triassic, becoming dominant ecological players in the Jurassic. These megaherbivores must have had high calorific requirements, indicating in turn that the associated vegetation must have provided large amounts of leafy material and have had a capacity for rapid regrowth (WIng \& Sues 1992; Gee 2011). Some authors have suggested that ferns in large marshlands were probably a major food source, especially for megaherbivores with low browsing ranges, such as the stegosauria (Krassilov 1981; Wing \& Sues 1992; HumMel et al. 2008). GEE (2011) compared the likeliness of different Mesozoic plant groups as potential food sources for the large sauropod dinosaurs, and concluded that Equisetum L. 1753, which was thought to have grown fast and formed large colonies in open areas, was one of the likely food sources. The two fern groups examined by GeE (2011; i.e. Osmundaceae Berchtold \& J. PRESL 1820 and Marattiaceae Kalf. 1824) were ranked as less likely food sources for the sauropods, despite having high energy contents, in part due to their preference for closed-canopy habitats, making them less accessible to the sauropods (GEE 2011). Certain osmundaceous ferns were noted to form dense thickets, and were considered as a possible minor part of the sauropod diet in mesic habitats (GEE 2011). In contrast, the slow growth and propagation of living Marattiaceae suggested that the Mesozoic relatives would have had a poor response to intense herbivore feeding pressures (GEE 2011). Interestingly, Equisetum, Osmundaceae and Marattiaceae fossils are all found in the Cerro Bayo site (Escapa \& CúneO 2012; EsCAPA et al. 2014; ElgorRIAGA et al. 2015).

In terms of growth habit and preferred habitat, Clathropteris meniscioides is more similar to Equisetum than either Osmundaceae or Marattiaceae. While we do not have detailed information on the rhizome structure of C. meniscioides from Cerro Bayo, Clathropteris material from Sweden as well as fossils of Thaumatopteris and Hausmannia, as well as all extant Dipteridaceae, are known to have horizontal, branching rhizome systems (RICHTER 1906; NATHORST 1906; NATHORST 1907; Chandra \& KAUR 1993). This low branching system would have allowed $C$. meniscioides to proliferate quickly on the floodplains, forming dense thickets (Text-fig. 3). Having multiple rhizome growth apices at ground level would reduce long-term damage incurred by browsing. Vein density 


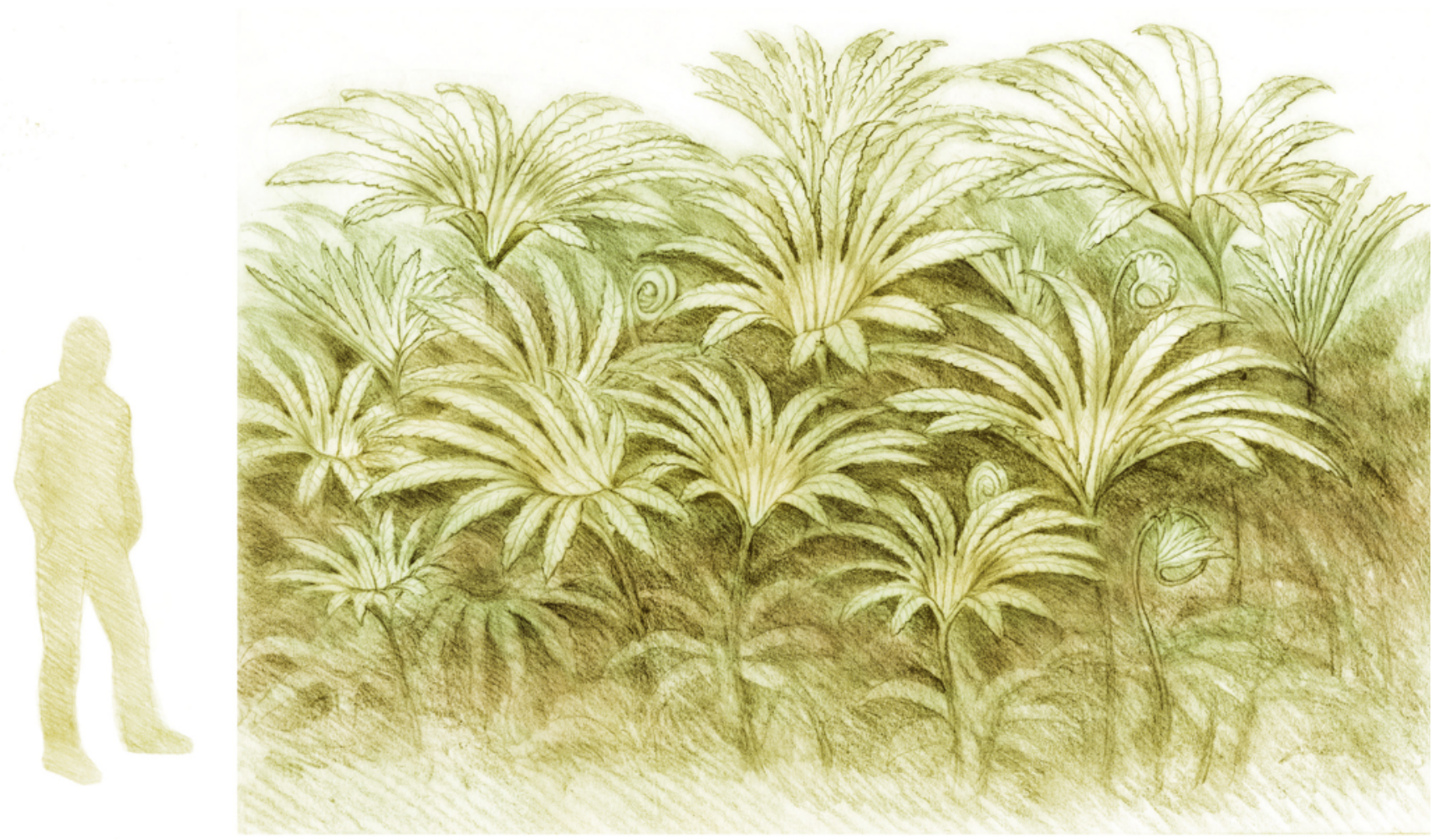

Text-fig. 3. Artist reconstruction of a Clathropteris meniscioides colony, with the silhouette of a person for scale.

evidence also suggests that $C$. meniscioides was likely to have much higher carbon assimilation rates than other lineages, including Osmundaceae and Marattiaceae, which are both free-veined lineages with relatively low vein densities $\left(1.5-2.5 \mathrm{~mm} \mathrm{~mm}^{-2}\right.$; BOyCE et al. 2009). This capacity for fast regrowth and high levels of production of leafy material makes $C$. meniscioides a prime candidate as fodder for megaherbivores.

Altogether, the presence of large colonies of $C$. meniscioides at Cerro Bayo suggests that the area was an open, flood-prone marshland during the Early Jurassic. Clathropteris meniscioides, with its very large fronds and fast-growing colonizing habit, was a prominent component of the vegetation and may have provided an important food source for local megaherbivores.

\section{Acknowledgements}

We would like to thank Julieta GALLEgo and Eduardo RuiGOMEZ for help with numbering and preparing the fossils, Aluar Aluminio Argentino (SAIC) and Jaime GroIZARd for help with the SEM, Polyanna von KNORRING (Stockholm) for the sketched reconstruction, Kevin NIXON (Ithaca) and Christian Ротт (Stockholm) for helpful discussion, and for the financial support provided by Cornell University, the National Parks Board of Singapore, Agencia Nacional de Promoción Científica y Tecnológica (PICT 1520 to IE) and the Swedish Research Council (VR; grant 2014-5232 to B.B.). Constructive comments by two anonymous reviews are gratefully acknowledged.

\section{References}

Armour, H. M. (1907): On the sorus of Dipteris. - New Phytol., 6: 238-244.

AsH, S. R. (1970): Ferns from the Chinle Formation (Upper Triassic) in the Fort Wingate area, New Mexico. - (United States Government Printing Office) Washington.

Bercovici, A., Hadley A. \& Villanueva-Amadoz, U. (2009): Improving depth of field resolution for palynological photomicrography. - Palaeontol. Electron., 12.

Berry, E. W. (1918): Notes on the fern genus Clathropteris. - B. Torrey Bot. Club, 45: 279-285.

Boersma, M. \& Broekmeyer, L. M. (1986): Index of figured plant megafossils Triassic 1976-1980. - Rev. Palaeobot. Palynol., 49: 235-344. 
BOMfLeUR, B. \& Kerp, H. (2010): The first record of the dipterid fern leaf Clathropteris BRONGNIART from Antarctica and its relation to Polyphacelus stormensis YAO, TAYLOR \& TAYLOR nov. emend. - Rev. Palaeobot. Palynol., 160: $143-$ 153.

Bonetti, M. I. (1963): Florula mesojurasica de la zona de Taquetren (Cañadon del Zaino) Chubut. - (Museo Argentino de Ciencias Naturales) Buenos Aires.

Boyce, C. K. (2005): Patterns of segregation and convergence in the evolution of fern and seed plant leaf morphologies. Paleobiology, 31: 117-140.

Boyce, C. K., Brodribb, T. J., Feild, T. S. \& Maciej, A. (2009): Angiosperm leaf vein evolution was physiologically and environmentally transformative. - Proc. R. Soc. London Ser. B, 276: 1771-1776.

Brodribb, T. J., Feild, T. S. \& Jordan, G. J. (2007): Leaf maximum photosynthetic rate and venation are linked by hydraulics. - Plant Physiol., 144: 1890-1898.

BrongNiART, A. (1825): Observations sur les végétaux fossiles renfermés dans les Grès de Hoer en Scanie. - Annls. Sci. nat., 4: 200-224.

Brongniart, A. (1828): Prodrome d'une histoire des végétaux fossiles. - (F. G. Levrault) Paris.

Cantrill, D. (1995): The occurrence of the fern Hausmannia Dunker (Dipteridaceae) in the Cretaceous of Alexander Island, Antarctica. - Alcheringa, 19: 243-254.

Chandra, S. \& Kaur, S. (1993): Vasculature of the rhizome in the fern genus Dipteris. - Am. Fern J., 83: 71-72.

Cornet, B. \& Traverse, A. (1975): Palynological contributions to the chronology and stratigraphy of the Hartford basin in Connecticut and Massachusetts. - Geoscience and Man, 11: 1-33.

Corsin, P. \& Waterlot, M. (1979): Palaeobiogeography of the Dipteridaceae and Matoniaceae of the Mesozoic. - In: LASKAR, B. \& RAO, C. S. R. (eds): Fourth International Gondwana Symposium Papers. - pp. 51-70 (Hindustan Publishing Corporation) Delhi.

Cúneo, R., Ramezani, J., Scasso, R., Pol, D., Escapa, I., Zavattieri, A. M. \& Bowring, S. A. (2013): High-precision $\mathrm{U}-\mathrm{Pb}$ geochronology and a new chronostratigraphy for the Cañadón Asfalto Basin, Chubut, central Patagonia: Implications for terrestrial faunal and floral evolution in Jurassic. - Gondwana Res., 24: 1267-1275.

Dijkstra, S. J. (1967): Fossilium catalogus, II: Plantae. Pars 67. Filicales, Pteridospermae, Cycadales, 40. - (Uitgeverij Dr Junk) 's-Gravenhage.

Elgorriaga, A., Escapa, I. H., Cúneo, R., Bomfleur, B. \& OTtone, E. (2015): Reconstruction and phylogenetic significance of a new Equisetum L. species from the lower Jurassic of Cerro Bayo (Chubut Province, Argentina). Ameghiniana, 52: 135-152.

Escapa, I. H., Cúneo, R. \& Axsmith, B. (2008): A new genus of the Cupressaceae (sensu lato) from the Jurassic of Patagonia: Implications for conifer megasporangiate cone homologies. - Rev. Palaeobot. Palynol., 151: 110-122.

Escapa, I. H., Bomfleur, B., Cúneo, R. \& SCAsso, R. (2014): A new marattiaceous fern from the Lower Jurassic of Patagonia
(Argentina): the renaissance of Marattiopsis. - J. Syst. Palaeontol., 13: 677-689. DOI: 10.1080/14772019.2014.936974

EsCAPA, I. H. \& CÚNEO, R. (2012): Fertile Osmundaceae from the Early Jurassic of Patagonia, Argentina. - Int. J. Plant Sci., 173: 54-66.

Fontaine, W. M. (1883): Contributions to the knowledge of the older Mesozoic flora of Virginia. - (U.S. Govt. Print. Office) Washington DC.

Frenguelli, J. (1941): Las Camptopterideas del Lias de Piedra Pintada en el Neuquén (Patagonia). - Rev. Mus. La Plata (N.S.). Paleontologia, 27: 27-57.

GEE, C. T. (2011): Dietary options for the sauropod dinosaurs from an integrated botanical and paleobotanical perspective. - In: Klein, N., Gee, C. T. \& SANDER, P. M. (eds): Biology of the sauropod dinosaurs: understanding the life of giants. - pp. 34-56 (Indiana University Press) Bloomington, Indiana.

Goeppert, H. R. (1841-1846): Die Gattungen der fossilen Pflanzen verglichen mit denen der Jetztwelt und durch $\mathrm{Ab}$ bildungen erläutert. - (Henry \& Cohen) Bonn.

Harris, T. M. (1961): The Yorkshire Jurassic flora. - (Trustees of the British Museum (Natural History)) London.

HeER, O. (1877): Flora fossilis Helvetiae die Vorweltliche Flora der Schweiz. - (Verlag von J. Wurster \& Comp.) Zürich.

Herbst, R. (1966): Revisión de la flora liásica de Piedra Pintada provincia de Neuquén Argentina. - Rev. Mus. La Plata (N.S.). Paleontologia, 30: 27-53.

Herbst, R. (1992): Propuesta de clasificación de las Dipteridaceae. - In: Asoc. Paleontol. Argent., Publ. Espec. 2. - pp. 69-72, VIII Simp. Argentino Paleobot. Palin., Buenos Aires.

Hiтchсоск, E. (1855): Description of a new species of Clathropteris discovered in the Connecticut Valley Sandstone. Am. J. Sci., 2: 22-25.

Holttum, R. E. (1954): A revised Flora of Malaya; an illustrated systematic account of the Malayan flora, including commonly cultivated plants. - (Govt. Printing Office) Singapore.

Hooker, W. J. (1853): Hooker's journal of botany and Kew Garden miscellany. 5. - (Lovell, Reeve, Henrietta Street) Covent Garden, London.

Hummel, J., Gee, C. T., Südekum, K. H., Sander, P. M., Nogge, G. \& Clauss, M. (2008): In vitro digestibility of fern and gymnosperm foliage: implications for sauropod feeding ecology and diet selection. - Proc. R. Soc. London Ser. B, 275: 1015-1021.

Jongmans, W. (1959): Fossilium catalogus, II: Plantae. Pars 37. Filicales, Pteridospermae, Cycadales, 10. - (Uitgeverij Dr Junk) 's-Gravenhage.

Kato, M., Yatabe, Y., Sahashi, N. \& Murakami, N. (2001): Taxonomic studies of Cheiropleuria (Dipteridaceae). - Blumea, 46: 513-525.

Kon’No, E. (1968): Some Upper Triassic species of Dipteridaceae from Japan and Borneo. - J. Linn. Soc. London Bot., 61: 93-105.

Kramer, K. U., Green, P. S. \& Götz, E. (1990): Pteridophytes and gymnosperms. - (Springer-Verlag) Berlin, New York. 
Krassilov, V. A. (1981): Changes of Mesozoic vegetation and the extinction of dinosaurs. - Palaeogeogr. Palaeoclimatol. Palaeoecol., 34: 207-224.

Kustatscher, E. \& van Konijnenburg-van Cittert, J. H. A. (2011): The ferns of the Middle Triassic flora from Thale. - N. Jb. Geol. Paläont., Abh., 261: 209-248.

LeHtonen, S. (2011): Towards resolving the complete fern tree of life. - PLoS One, 6: e24851. DOI:24810.21371/journal.pone.0024851.

Litwin, R. J. (1985): Fertile organs and in situ spores of ferns from the late Triassic Chinle Formation of Arizona and New Mexico, with discussion of the associated dispersed spores. - Rev. Palaeobot. Palynol., 44: 101-146.

Nathorst, A. G. (1906): Bemerkungen über Clathropteris meniscioides BRONGNIART und Rhizomopteris cruciata NATHORST. - Kungliga Svenska Vetenskapsakademiens Handlingar, 41: 1-14.

Nathorst, A. G. (1907): Ueber Thaumatopteris schenki NATHORST. - Kungliga Svenska Vetenskapsakademiens Handlingar, 42: (3).

Oishi, S. (1932): The Rhaetic plants from the Nariwa district, Prov. Bitchû (Okayama Prefecture), Japan. - J. Fac. Sci. Hokkaido Imp. Uni. Ser. 4, Geology and Mineralogy, 1: 257-380.

Orshi, S. (1940): The Mesozoic floras of Japan. - J. Fac. Sci. Hokkaido Imp. Uni. Ser. 4, Geology and Mineralogy, 5: 123-480.

Oishi, S. \& Yamasita, K. (1936): On the fossil Dipteridaceae. - J. Fac. Sci. Hokkaido Imp. Uni. Ser. 4, Geology and Mineralogy, 3:135-181.

Potт, C. (2012): The Upper Triassic flora of Svalbard. - Acta Palaeontol. Pol. 59: 709-740.

Rees, P. M. (1993): Dipterid ferns from the Mesozoic of Antarctica and New Zealand and their stratigraphical significance. - Palaeontology, 36: 637-656.

RichteR, P. B. (1906): Beiträge zur Flora der unteren Kreide Quedlinburgs. Teil I. Die Gattung Hausmannia Dunker und einige seltenere Pflanzenreste. - (Verlag von Wilhelm Engelmann) Leipzig.

Schuettpelz, E. \& Pryer, K. M. (2007): Fern phylogeny inferred from 400 leptosporangiate species and three plastid genes. - Taxon, 56: 1037-1050.

Schweitzer, H.-J., Schweitzer, U., Kirchner, M., van Konijnenburg-van Cittert, J. H. A., van der Burgh, J. \& Ashraf, R. A. (2009): The Rhaeto-Jurassic flora of Iran and Afghanistan. 14. Pteridophyta - Leptosporangiatae. - Palaeontographica Abt. B, 279: 1-108.
SEwARD, A. C. (1900): La flore wealdienne de Bernissart. Mem. Mus. Roy. Hist. Nat. Belg., 1: 1-37.

Seward, A. C. \& Dale, E. (1901): On the structure and affinities of Dipteris, with notes on the geological history of the Dipteridinae. - Phil. Trans. R. Soc. London, Ser. B, 194: 487-513.

SkoG, J. E. (2001): Biogeography of Mesozoic leptosporangiate ferns related to extant ferns. - Brittonia, 53: 236-269.

Stockey, R. A., Rothwell, G. W. \& Little, S. A. (2006): Relationships among fossil and living Dipteridaceae: anatomically preserved Hausmannia from the lower Cretaceous of Vancouver Island. - Int. J. Plant Sci., 167: 649-663.

Tidwell, W. D. \& AsH, S. R. (1994): A review of selected Triassic to early Cretaceous ferns. - J. Plant Res., 107: 417442.

van Konijnenburg-van Cittert, J. H. A. (2002): Ecology of some late Triassic to early Cretaceous ferns in Eurasia. Rev. Palaeobot. Palynol., 119: 113-124.

WANG, Y. (2002): Fern ecological implications from the Lower Jurassic in Western Hubei, China. - Rev. Palaeobot. Palynol., 119: 125-141.

Wang, Y., Wu, X., YAng, X., DuAn, W. \& LI, L. (2014): The discovery of Jurassic plants in Shenzhen of Guangdong, southern China and related significance. - Chin. Sci. Bull., 59: $3630-3637$.

Wang, Y., Li, L., Guignard, G., Dilcher, D. L., Xie, X., Tian, N. \& Zhou, N. (2015): Fertile structures with in situ spores of a dipterid fern from the Triassic in southern China. - J. Plant Res., 128: 445-457.

WebB, J. (1982): Triassic species of Dictyophyllum from Eastern Australia. - Alcheringa, 6: 79-91.

Wing, S. L. \& Sues, H.-D. (1992): Mesozoic and early Cenozoic terrestrial ecosystems. - In: Behrensmeyer, A. K., Damuth, J. D., DiMichele, W. A., Potts, R., Sues, H.D. \& Wing, S. L. (eds): Terrestrial ecosystems through time; Evolutionary paleoecology of terrestrial plants and animals. - pp. 327-416 (The University of Chicago Press) Chicago and London.

Yao, X., TAYlor, T. N. \& TAYlor, E. L. (1991): Silicified dipterid ferns from the Jurassic of Antarctica. - Rev. Palaeobot. Palynol., 67: 353-362.

Zeiller, R. (1903): Flore fossile des gîtes de charbon du Tonkin. - Imprimerie Nationale, Paris.

Zhou, N., WANG, Y., Li, L. \& Zhang, X. (2015): Diversity variation and tempo-spatial distributions of the Dipteridaceae ferns in the Mesozoic of China. - Palaeoworld, 25: 263-286. DOI: 10.1016/j.palwor.2015.11.008 


\section{Plates 1-6 and explanation of plates}

Plate 1

Single specimen of Clathropteris meniscioides (BRONGN. 1825) BRONGN. 1828. The specimen is composed of two counterparts and shows the relative positions of the frond and stipe. $($ Scale bar $=2 \mathrm{~cm}$ )

Fig. 1. Top view of the specimen, showing two halves of the bilaterally symmetrical frond.

Fig. 2. Side view of one half of the specimen, showing the upright stipe, branching pattern of one rachial arm and one half of the frond. 


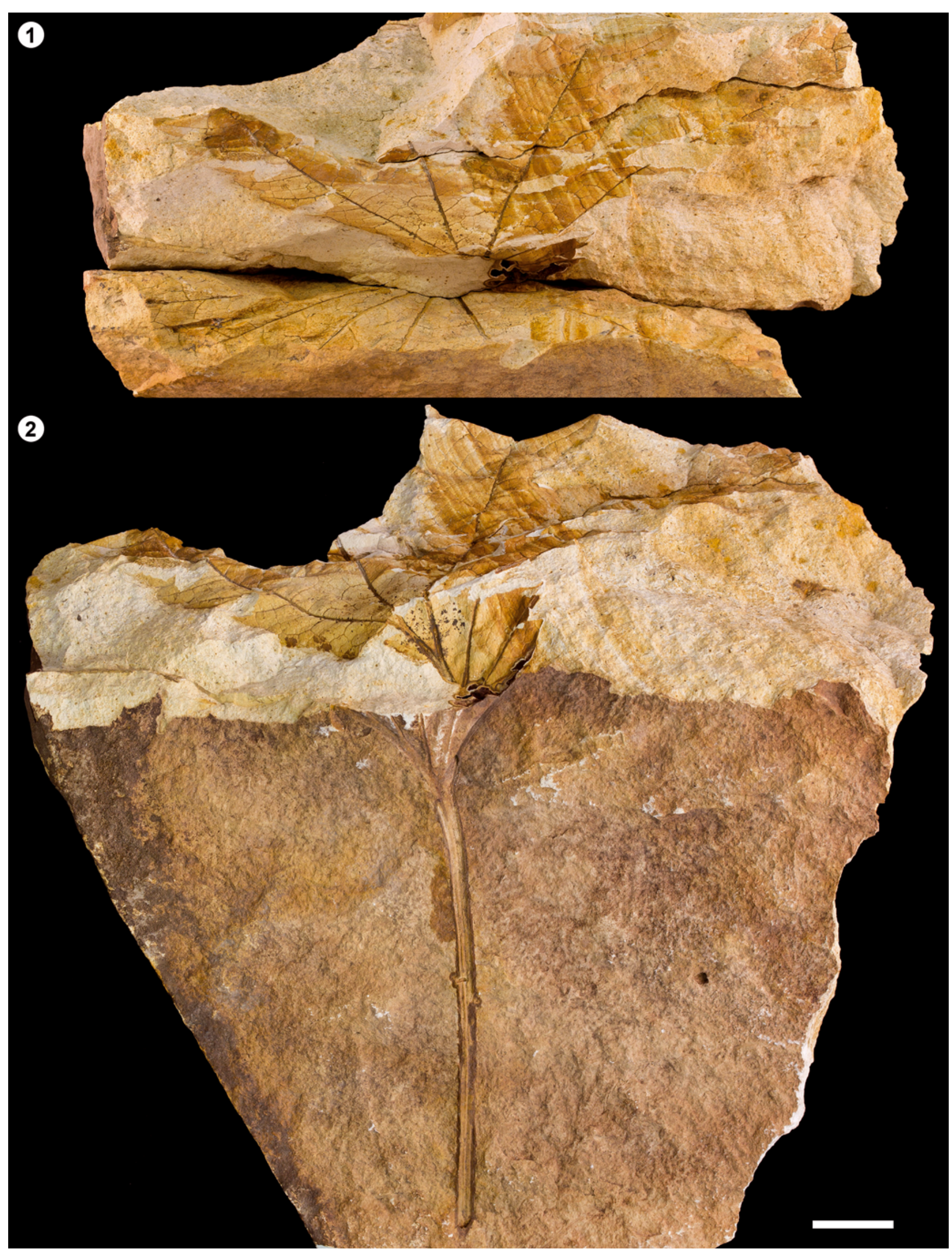

Plate 1. CHOo et al. 
Plate 2

Variously sized specimens of Clathropteris meniscioides (BRONGN. 1825) BRONGN. 1828 showing the rachial arm architecture.

Fig. 1. Near-complete frond with the largest complete primary segment of the entire collection indicated (arrowhead). $($ Scale bar $=6 \mathrm{~cm})$

Fig. 2. Specimen with the largest stipe. (Scale bar $=5 \mathrm{~cm}$ )

Figs 3-4. Specimens showing catadromously branching rachial arm. (Scale bars $=1 \mathrm{~cm})$ 


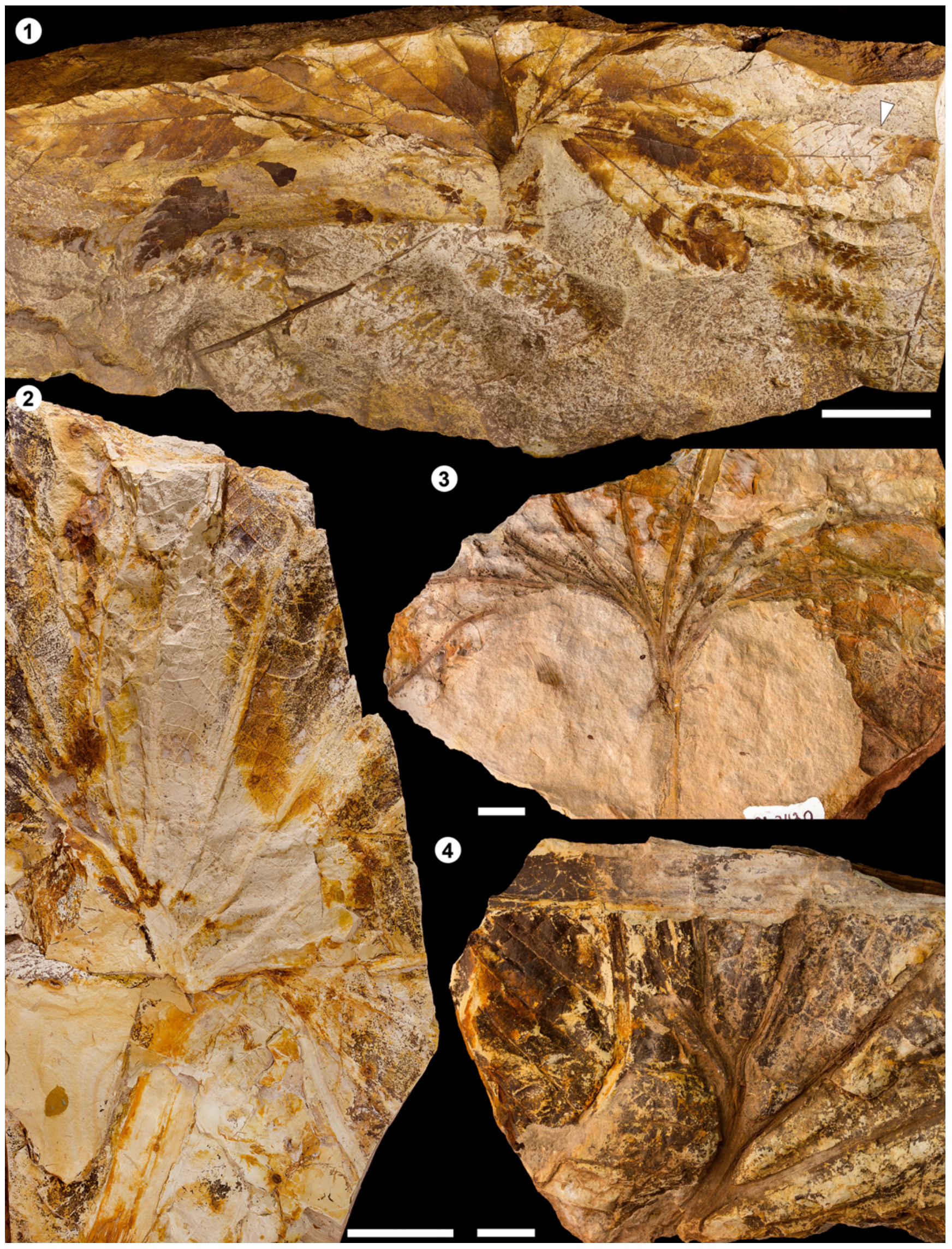

Plate 2. CHoo et al. 
Plate 3

Primary segments of Clathropteris meniscioides (BRONGN. 1825) BRONGN. 1828

Fig. 1. Largest (incomplete) primary segment. Lamina teeth are found throughout the length, indicating that this fragment is from the distal, free end of the frond. (Scale bar $=2 \mathrm{~cm}$ )

Fig. 2. Specimen showing the basal region of a frond where the lamina between primary segments is fused. ( $(S c a l e b a r=2 \mathrm{~cm})$

Fig. 3. Fragment of a primary segment showing laminal teeth. $($ Scale bar $=2 \mathrm{~cm})$ 


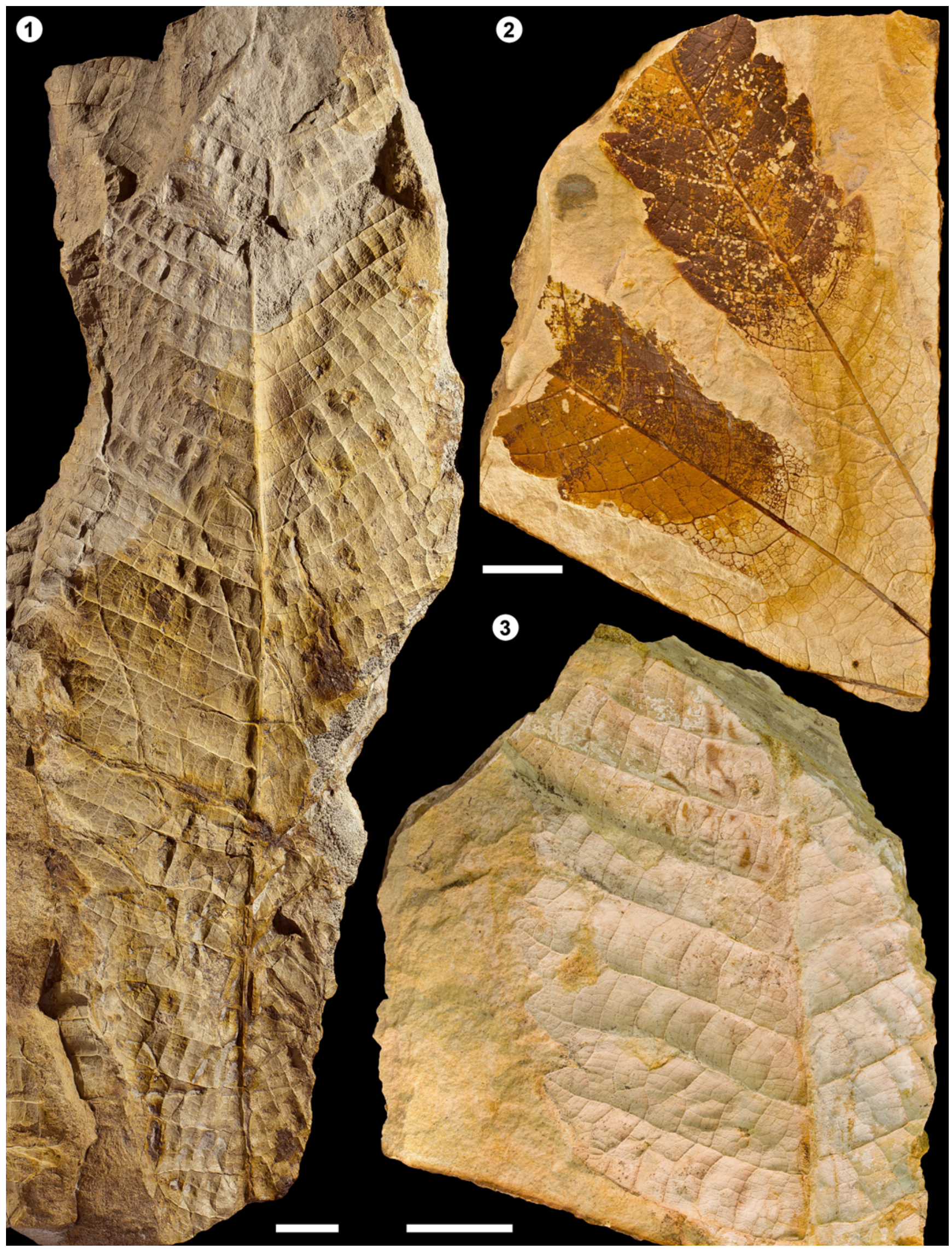

Plate 3. CHoo et al. 


\section{Plate 4}

Frond lamina and venation details of Clathropteris meniscioides (BRONGN. 1825) BRONGN. 1828

Fig. 1. Specimen showing rachial arm architecture and disposition of primary segments. $(S c a l e ~ b a r=2 \mathrm{~cm})$

Fig. 2. Lanceolate to oblanceolate primary segment. $(S$ cale bar $=2 \mathrm{~cm})$

Fig. 3. Near complete frond showing toothed, lanceolate primary segments. (Scale bar $=2 \mathrm{~cm}$ )

Fig. 4. Details of venation in the fused portion of the lamina. The secondary and tertiary vein paths are irregular and sometimes indistinguishable, and the areoles formed between secondary and tertiary veins are irregular polygons. $(S c a l e ~ b a r=1 \mathrm{~cm})$

Fig. 5. Free portion of a primary segment showing the orthogonal areoles formed by the secondary and tertiary veins. $($ Scale bar $=1 \mathrm{~cm})$

Fig. 6. Details of tertiary vein paths between two secondary veins. Most tertiary veins are monopodial; an occasional sympodial tertiary vein is indicated with arrowheads. (Scale bar $=5 \mathrm{~mm}$ )

Fig. 7. Close up of two areoles formed by secondary (vertical) and tertiary (horizontal) veins. Mesh of squarish ultimate areoles formed by higher order veins visible (Scale bar $=2 \mathrm{~mm}$ ) 


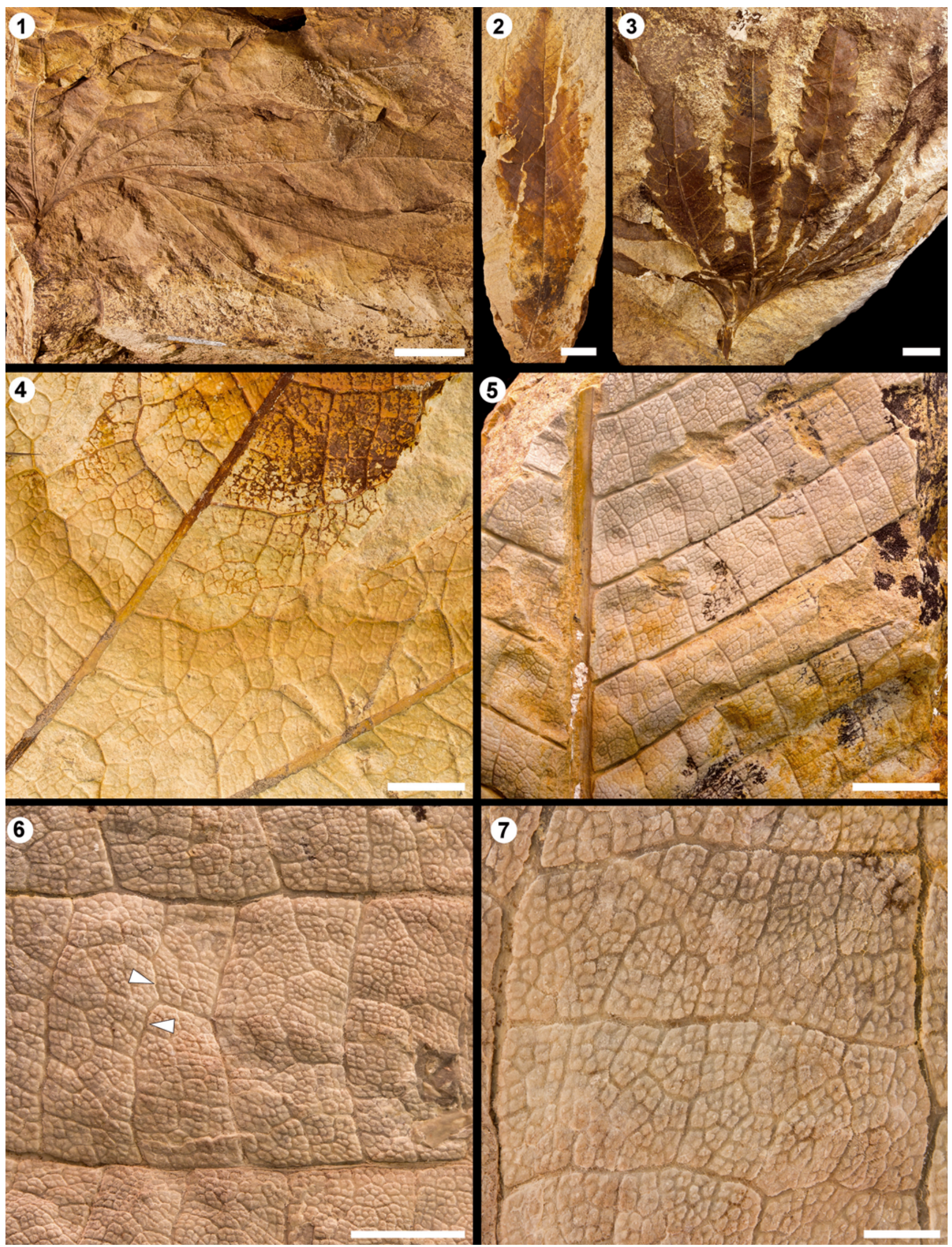

Plate 4. CHOo et al. 


\section{Plate 5}

Details of Clathropteris meniscioides (BRONGN. 1825) BRONGN. 1828

Fig. 1. Secondary veins ending in marginal teeth. $($ Scale bar $=1 \mathrm{~cm})$

Fig. 2. Apex of a primary segment. (Scale bar $=1 \mathrm{~cm}$ )

Fig. 3. Rare occurrence of secondary veins anastomosing (indicated by arrowhead). (Scale bar $=1 \mathrm{~cm})$

Fig. 4. Close up of the abaxial surface of the stipe, showing two parallel longitudinal grooves. (Scale bar $=2 \mathrm{~mm})$

Fig. 5. Large structure that is either a stipe or creeping rhizome. (Scale bar $=2 \mathrm{~cm}$ )

Fig. 6. Cross section through a stipe, showing a single C-shaped vascular bundle with the incurved tips. (Scale bar $=0.5 \mathrm{~mm})$

Fig. 7. Crozier. (Scale bar $=1 \mathrm{~cm}$ ) 

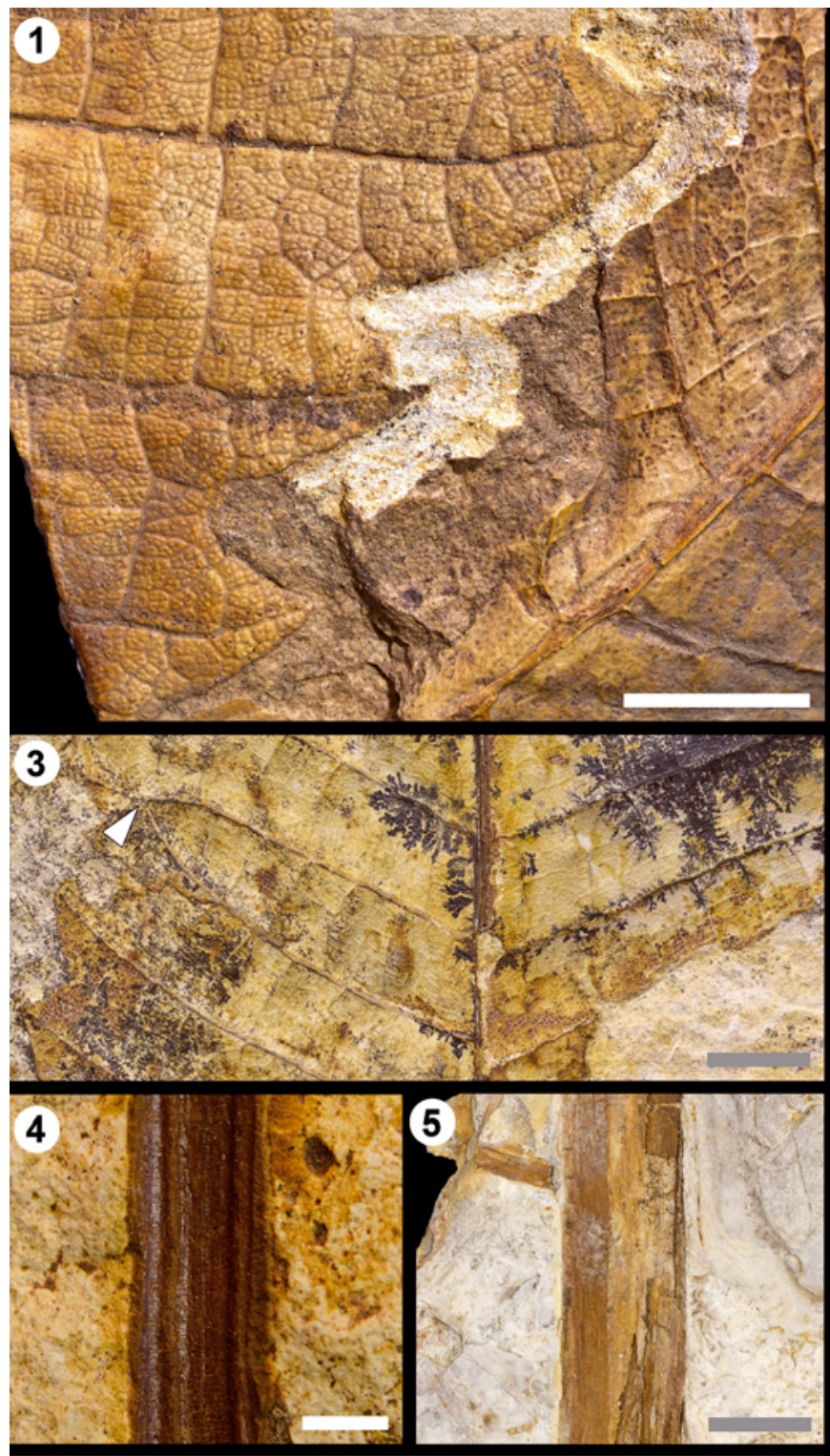

6
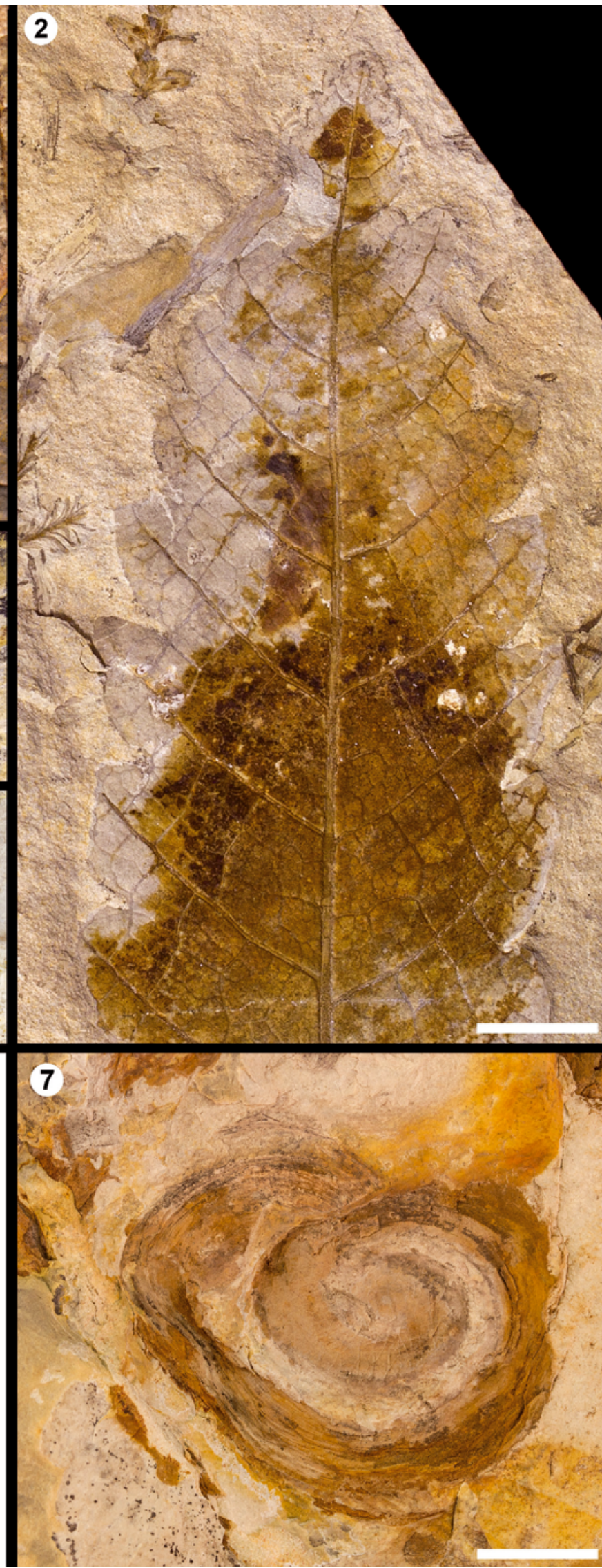

Plate 5. CHoo et al. 


\section{Plate 6}

Reproductive characters of Clathropteris meniscioides (BRONGN. 1825) BRONGN. 1828

Figs 1-2. Circular sori scattered across frond lamina of primary segments. (Scale bar $=1 \mathrm{~cm})$

Fig. 3. Sori becoming more dispersed towards frond margin. (Scale bar $=6 \mathrm{~mm}$ )

Fig. 4. Close up of lamina showing sori positioned within ultimate areoles. (Scale bar $=2 \mathrm{~mm}$ )

Fig. 5. Sori showing individual sporangia. (Scale bar $=1 \mathrm{~mm}$ )

Fig. 6. Close up of lamina showing impressions of several sporangia with prominent annuli. $($ Scale bar $=0.3 \mathrm{~mm})$

Fig. 7. Close up of a sporangium showing uniseriate annulus. (Scale bar $=0.3 \mathrm{~mm}$ )

Fig. 8. SEM photograph of a sporangium with part of the annulus visible. (Scale bar $=0.1 \mathrm{~mm}$ ) 


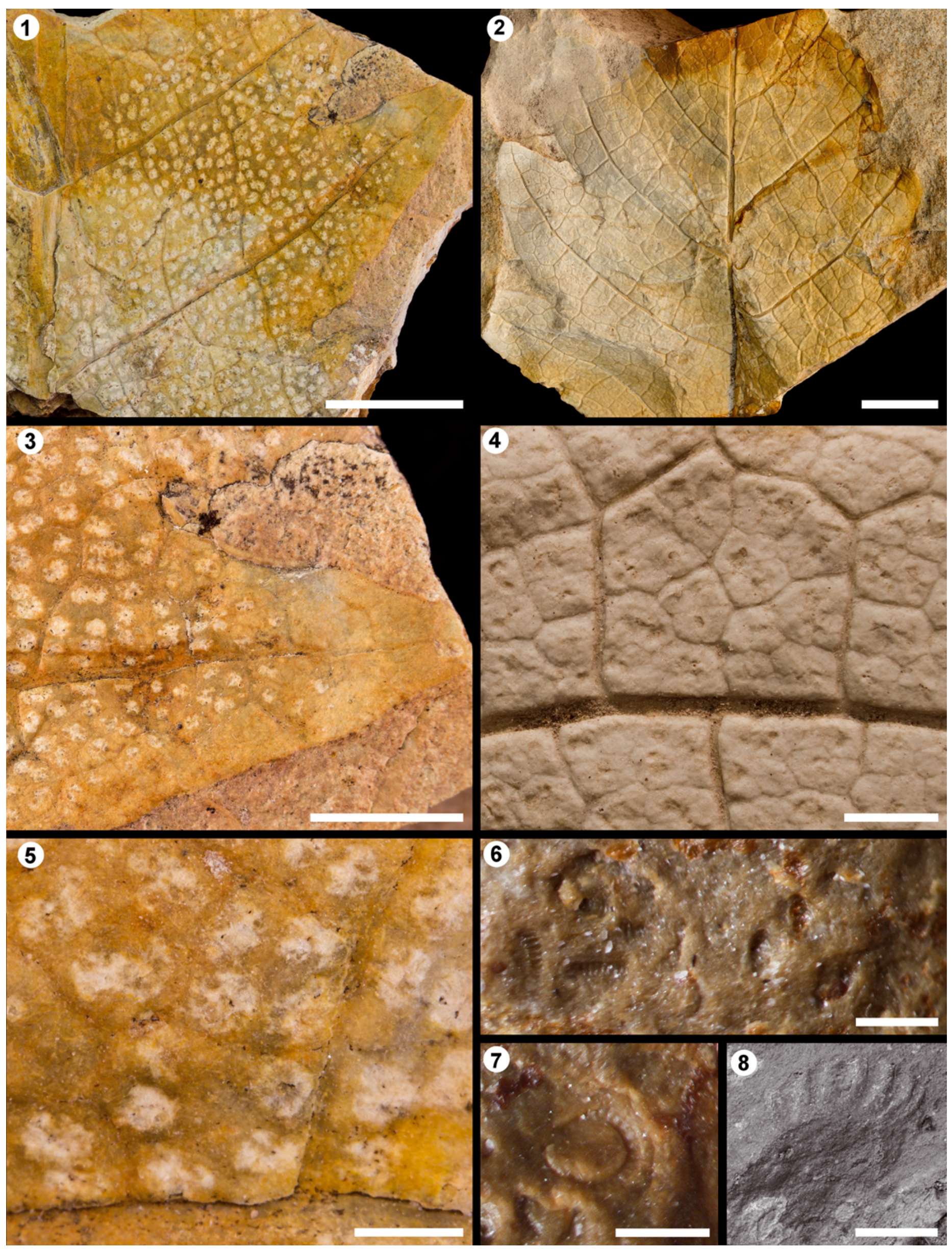


